\title{
OS SENTIDOS DA DEMOCRACIA: CRÍTICA, APOSTA E PERPLEXIDADE NA PRODUÇÃO DO CENEDIC
}

José Szwako

\section{Introdução}

O debate acerca das transformações que marcaram a construção democrática brasileira foi permeado, desde fins da década de 1970, por dissidências e tensões intelectuais em torno das quais se opuseram distintas interpretações. Em tal contexto, a questão que afastava ou aproximava as várias posições era saber qual o sentido político-normativo assumido pela atuação de diferentes atores e grupos sociais nos diferentes níveis daquela construção. Se um conjunto de autores se voltava para os cálculos e custos dos chamados “atores relevantes" e, ainda, para os limites de cunho institucional na transição, outros se perguntavam sobre a performance de atores sociais tais como os trabalhadores e os movimentos sociais sobre e naquele contexto. Neste segundo eixo de reflexão e problematização, ao longo da década de 1980, surgiram questões que rapidamente se tornariam sínteses fortes no e do debate acadêmico brasileiro: qual é e como se dá a relação destes atores sociais com os partidos então em formação? Essa relação implica uma representação de classe? Quais são os efeitos advindos da mobilização 
associativa e reivindicatória dos movimentos sociais? Eles devem se relacionar com o Estado, permanecer "de costas" para ele, ou devem se manter imaculados, como um dia pretendeu Touraine? Seriam os movimentos sociais capazes de substituir a representação político-partidária ou mesmo de classe? Em todo caso, eles pretendiam tal substituição? Foi ao redor de questões como essas que girou parte significativa da produção da Antropologia, da Sociologia e da Ciência Política brasileiras. Grosso modo, a década seguinte foi marcada por uma multiplicação de categorias e de posturas teóricas que, partindo de autores tão diversos como Habermas, Gramsci e Foucault, tentavam dar conta da complexidade, das ambiguidades e, em especial, dos limites inerentes à performance dos atores sociais com relação aos sentidos da construção democrática.

Para responder estas questões ou algumas delas, e muito embora as respostas levantadas tenham variado no mesmo polo ideológico do campo intelectual, ${ }^{1}$ os pesquisadores e centros de pesquisa envolvidos no debate passaram a se utilizar de categorias forjadas na atuação dos movimentos sociais durante a redemocratização. Por um lado, noções como direitos e cidadania tornaram-se "ideias fundantes" ${ }^{2}$ e foram gradualmente incorporadas ao rol de categorias ao debate acadêmico. ${ }^{3}$ Por outro, essa incorporação e o reco-

\footnotetext{
1 Tal como foi o caso das posições de Eunice Durham (1984) e de Ruth Cardoso (1983).

2 "Não é de espantar, portanto, que as ciências humanas acolham a noção de $c i$ dadania e de direitos como uma das ideias fundantes sobre o Brasil de hoje" (Paoli 1989 , p. 40 - grifos no original).

${ }^{3}$ Esse processo de incorporação e de tradução de categorias levado a cabo durante a década de 1980, cujo ponto paradigmático é a reflexão de Sader (1988), merece análise própria. No entanto, vale notar que a "entrada" desses personagens em cena e o gradual e correlato acolhimento intelectual da "novidade" encerrada em seus discursos, ambos levaram algum tempo para serem levados a sério. Neste sentido, excelente pista dos contornos do debate sobre a transição e, nela, sobre o papel da esquerda com relação a trabalhadores e atores populares, pode ser vista nas reações ao texto "Crise Política e Democracia", de J. A. Moisés, sintetizadas no debate "A Democracia é Possível?”, de março de 1980. Ali, M. Chauí se
} 
nhecimento da relevância de um mar de atores e anseios sociais trazidos a público encerravam um belo dilema teórico-normativo: qual é o estatuto desses atores e de seus anseios? Eles merecem a designação de "político"? Isso é Política? - certa vez se questionou Ruth Cardoso. ${ }^{4}$ Se não, por quê? Se sim, o que dá a eles tal politicidade? Aceitar o desafio de se colocar e de responder questões desse naipe implicava levantar argumentos político-normativos orientados por uma matriz de tom predominantemente mais liberal, mais elitista, mais republicano, mais marxista, ou, ainda, de uma combinação de alguns desses tons.

Partindo do contexto de debate herdado dos anos 1980, este artigo visa elucidar uma posição específica no campo de interpretações sobre as possibilidades democráticas do Brasil pós-1988. Trata-se da posição defendida por um renomado grupo de sociólogos que, até fins da década de 1990, escolheu responder positivamente a uma daquelas questões: sim - diziam aqueles sociólogos -, os movimentos sociais têm estatuto político, mais precisamente, estão "em busca de tal estatuto". 5 Tal posição pode ser encontrada em parte da produção de Maria Célia Paoli, Francisco de Oliveira e Vera da Silva Telles, teóricos cuja postura e reflexão são, desde então, referências obrigatórias no debate. Diante da produção destes auto-

indaga: " $[\mathrm{Eu}]$ tenho me perguntado $[\ldots]$, ao ver as reivindicações dos movimentos populares e algumas propostas de oposição serem absorvidas pelo governo e transformadas em propostas governamentais, se não seria o caso de analisarmos o teor dessas propostas e seu modo de absorção. [...] Tenho me perguntado se um dos aspectos da "crise" da esquerda não está no fato de que, em nome de um "realismo" nunca explicitado, a esquerda nunca faça uma análise da realidade política, de tal modo que pudesse ter propostas cujo grau de avanço histórico impossibilitaria sua absorção pelo governo. Será que o "realismo" e a "cautela" não são sinais de uma crise que a esquerda não pode nem quer enfrentar? [...] $\mathrm{E}$, sobretudo, porque ela [a esquerda] não está sendo capaz de compreender a novidade que está surgindo? Que tipo de prática a esquerda pretende, prática que acaba bloqueando a compreensão das coisas novas?” (1980, pp. 52-53).

${ }^{4}$ Veja Cardoso (1988).

${ }^{5}$ Veja Paoli (1995). 
res e à resposta provisoriamente afirmativa nela encerrada quanto ao caráter político dos movimentos sociais, este texto pretende acompanhar a trajetória das concepções de "cidadania" e de "política" aí veiculadas. ${ }^{6}$ A recomposição dessa trajetória se dá, por um lado, no espaço intertextual que aproxima e atravessa as reflexões empreendidas por esses sociólogos e, por outro lado, no diálogo travado com Roberto Schwarz e, mais indiretamente, com Laymert Garcia dos Santos e, ainda, em relação a alguns de seus adversários político-teóricos. No seu todo, o texto pretende elucidar a principal inflexão daquela produção e, a partir daí, lançar algumas hipóteses a respeito do tom predominante e corrente na análise dos autores agrupados, desde fins dos 1990, em torno do Centro de Estudos dos Direitos da Cidadania, Cenedic, ${ }^{7}$ da Universidade de São Paulo. A importância e a relevância de perscrutar a trajetória de parte do pensamento desses autores residem 254 no reconhecimento de que suas reflexões ocupam posição estabelecida no campo de debate sociológico e vão além, de forma a influenciar e inspirar vários atores políticos $\mathrm{e}$ civis brasileiros.

De forma bastante concisa, nosso argumento enfatiza a transformação operada particularmente no uso da noção

\footnotetext{
${ }^{6}$ Embora a maior parte dos textos aqui utilizados tenha circulação propriamente acadêmica, apresentamos uma reflexão de Oliveira (1994b), orientada para discussão com uma organização civil. Além do texto-diálogo, por cujo acesso agradeço ao Centro de Estudos e Documentação da America Latina de Amsterdam, são dispostas aqui algumas das tomadas públicas de posição do sociólogo espalhadas em revistas acadêmicas e jornais brasileiros.

${ }^{7}$ Não cabe aqui tentar um perfil institucional do Cenedic. Para os fins desta análise, basta apenas notar que, embora teórica e internamente heterogêneo, esse grupo é atravessado por um repertório crítico e por um tom comum de abordagem. Seus principais pesquisadores estão relacionados na dedicatória de Francisco de Oliveira a "O Ornitorrinco" e na introdução de "Nas tramas da cidade"(2006), organizado por Vera Telles e Robert Cabanes. Além de Maria Célia Paoli, Francisco de Oliveira e Vera da Silva Telles, fazem parte do Cenedic nomes como Cibele Rizek, Laymert Garcia dos Santos, Ana Amélia da Silva, Maria Carmelita Yazbek e Leonardo Mello e Silva, dentre outros.
} 
de "política" e no raciocínio a ele subjacente: se, durante boa parte dos anos 1990, as potencialidades encerradas na performance dos movimentos sociais e na própria dinâmica sociopolítica brasileira permitiam falar da política como construção conflituosa e historicamente possível, o trabalho de "desmanche", termo alcunhado por Roberto Schwarz e compartilhado pelos sociólogos do Cenedic para designar a despolitização operacionalizada a partir dos dois mandatos presidenciais de Fernando Henrique Cardoso, desencantou a aposta naquelas potencialidades. Com base nessa inflexão e no tom desencantado por ela veiculado, o argumento do texto defende que essa transformação deve ser entendida, não apenas em função da mudança histórica levada a cabo no bojo da mundialização do capital e de processos correlatos, mas também através das relações político-intelectuais travadas com e contra outras interpretações a respeito dos sentidos da democracia brasileira. Assim, a discussão levantada não trata de posições substantivamente defendidas, em particular, quanto à natureza do potencial dos atores civis, sejam eles movimentos sociais ou ONG. O argumento mais de fundo parte do pressuposto de que, mesmo sob condições de relativo desencanto cognitivo, a partir do qual estes e outros atores não encarnam a priori qualquer pureza imaculada dos valores democráticos (Dagnino, 2002), a análise crítica não precisa prescindir de um componente utópico aberto a contradições e ambiguidades neles encerradas relativamente ao aprofundamento democrático. Neste sentido, ao fornecer pistas para entender o campo político-intelectual no qual aquela aposta foi forjada e, posteriormente, a possibilidade mesma da política foi erodida, não se está criticando seu ímpeto notadamente crítico, mas, muito antes, a negação categorial da qual ele parte, que forçosa e desnecessariamente carrega e cuja gênese parece negar. 


\section{Anos 1990: possibilidade política e construção hegemônica} Em "Movimentos Sociais no Brasil: em busca de um estatuto político", Paoli faz um levantamento do debate acadêmico que, nas décadas de 1970 e 80, buscou compreender a atuação dos movimentos sociais, novos e velhos, no contexto da redemocratização. Ali, duas posições se opunham no que diz respeito ao papel político desempenhado pelos movimentos populares, assim como pelo movimento negro e de mulheres/feminista. De um lado, havia o grupo de autores que, embora celebrasse a atuação dos movimentos, sustentava que estes "jamais poderiam ou deveriam ameaçar as ainda frágeis negociações em direção a um Estado de Direito" (Paoli, 1995, p. 36). De acordo com tal perspectiva, ${ }^{8}$ não apenas a eficácia política dos movimentos era questionada, dado que não encarnavam e tampouco representavam os atores políticos por excelência, como sua atuação não era vista como politicamente desejável em um 256 contexto particularmente marcado pelas "incertezas” dos "cenários de transição". De outro lado, ${ }^{9}$ estavam aqueles

\footnotetext{
${ }^{8}$ Exemplo dessa perspectiva, embora posteriormente autocriticada (Cardoso, 1994), está sintetizada na ideia de que "decretar o nascimento de novos atores políticos, portadores de uma força transformadora, sem que a análise demonstre concretamente a novidade de seu papel mediador entre sociedade civil e o Estado parece incompleto. [...] Os movimentos de bairro, quando vistos por sua face reivindicativa, não parecem capazes de grandes transformações, mas quando os vemos como expressão de uma nova identidade, é possível pensar que venham a ser uma nova peça no jogo político" (Cardoso, 1983, pp. 219 e 238). Mais taxativa, no entanto, é a posição de outro Cardoso (1993), que diz: "É compreensível e salutar que em países como o Brasil - de tradição elitista [...] - haja a valorização dos movimentos sociais e que se desenvolva uma atitude ética de solidariedade com as bases. Mas é teoricamente insatisfatório e politicamente pouco eficaz imaginar uma política de transformação social que não diga o que fazer no e com o Estado para redirecioná-lo em benefício da maioria. Não obstante, existe hoje uma tendência não apenas "basista" (cega à compreensão destas questões), mas que se esquece de que [...] a ideologia das classes dominantes e a prática da dominação marcam os dominados na sua subjetividade" (Cardoso, 1993, p. 265).

9 Posição que sintetiza este outro "lado" do debate está na descrição de Sader e Paoli: "O que parece estar saindo como um novo modo de se entender os trabalhadores e os movimentos populares como um conjunto de pessoas e grupos que
} 
autores que preferiram sublinhar o "alargamento" promovido pelos movimentos sociais em diferentes níveis da realidade brasileira. Tal alargamento, como aponta a autora, se deu no espaço das práticas consideradas propriamente políticas, isto é, retirou a Política dos "limites da representação democrático-formal"; e, além disso, tinha a capacidade de reconhecer a "legitimidade dos conflitos na esfera da sociedade, algo que a cultura política brasileira jamais aceitou" (Paoli, 1995, pp. 36-37).

Este texto, além de enfatizar algumas das novidades de caráter organizacional, ideológico e participativo dos novos movimentos, ilustra de forma exemplar o debate sobre a democratização. Para aquilo que nos interessa, a reflexão de Paoli mostra, a um só tempo, a sua posição e a concepção de "política" subjacente ao seu raciocínio. Em âmbito político-normativo, a autora se alinha àquele conjunto de autores que prefere afirmar positivamente o potencial democratizante dos novos atores coletivos. Isso, contudo, não se deve ao conteúdo substantivo de suas reivindicações, muito antes, se deve ao estilo de mobilização e de organização marcado pela veiculação de "identidades diferenciadas", por uma "prática coletiva identitária" e por "formas internas não hierárquicas" operantes nos novos movimentos. Essa tomada de posição, que em certo sentido pode ser dita "a favor" dos movimentos, é indissociável daquilo que a autora concebe e pressupõe como sendo "política”. Ao descrever algumas das "invenções democráticas" impelidas pelos movimentos, seu texto fornece índices normativos em torno dos quais se age politicamente,

têm algo em comum é, na verdade, o extraordinário momento de lutas múltiplas que emergiram depois de 78. Os pesquisadores das ciências sociais dos anos 80 se viram diante de um momento político marcado por movimentos vários de luta contra opressões diversas, a maioria de base popular, cuja promessa tirava de cena os atributos de 'alienação' e heteronomia tradicionalmente atribuídos aos trabalhadores" (Sader e Paoli, 1986, p. 61). 
isto é, ele oferece pontos a partir dos quais o espaço da política é estruturado, redefinido e "alargado". Tais índices seriam "negociação", "interlocução", "resolução de conflitos", "explicitação", "mobilizações", "lutas" e "diferenças" (Paoli, 1995, p. 47). A descrição de Paoli sobre o significado político dos movimentos sociais é acompanhada pari passu por uma noção de política que extrapola a representação institucional, rumo à constituição daquilo que ela designa como "campo de práticas legítimas de invenção, conflito e negociação” (Paoli, 1995, p. 32).

Em linhas gerais, o argumento da autora se volta para a atuação dos movimentos sociais de forma a destacar, por um lado, as "referências novas" por eles tematizadas para o conjunto social mais amplo, e por outro lado, o exercício de "invenção radical” (Paoli, 1995, p. 27) da democracia. Entretanto, ao falar da "invenção democrática" e do "alargamento da política”, Paoli e o conjunto

258 de autores "a favor" dos movimentos parecem não saber se estavam tratando de uma constatação empírica ou de uma aposta normativa. Em seu dado contexto, esses autores viam pela primeira vez na história brasileira uma potencialidade real de construção hegemônica, desencadeada em parte pelo novo arranjo semântico dos movimentos sociais entendido como tradução "popular" de demandas e conflitos sociais; esse grupo de autores via, não sem certo fascínio, que o

"espaço de negociação dialógica (entre governos e movimentos, entre classes sociais antagônicas) abre [...] uma dimensão insuspeitada para a criação das regras democráticas que levam os limites da democracia formal para muito além de si mesma: em direção da criação da lei democrática, pensada como construção de uma medida comum entre forças conflitantes, que expressam a criação de novos direitos" (Paoli, 1995, p. 46 - grifos nossos). 
Gostaria de mostrar, por meio da concepção de política, como essas duas dimensões textuais - aposta e constatação, juízos de valor e de fato - estão recíproca e fortemente implicadas. Primeiramente, é possível observar que a noção de "política" subjacente à descrição, além e aquém de seus pressupostos teóricos, implica pensar que diferentes atores sociais, (ainda que) a partir de posições estruturalmente desiguais, podem potencial e realmente construir uma "medida comum" via reconhecimento do conflito e, por meio da ampliação de direitos, expandir os níveis de conflitualidade. Em segundo lugar, é importante notar que estes autores observavam um conjunto de experiências sui generis e concretas, que servia de base para afiançar uma aposta de tom otimista. Dentre tais experiências estava o chamado "acordo das montadoras", que, embora tenha sido esquadrinhado em "Quanto melhor, melhor"(Oliveira et al., 1993), foi sintetizado de forma brilhante e contundente por Francisco de Oliveira em sua "Carta aberta ao ministro Fernando Henrique Cardoso": ${ }^{10}$

"O chamado 'acordo das montadoras' tem sido objeto de críticas contundentes na imprensa nacional e em respeitáveis revistas acadêmicas. [...]

Este argumento, aparentemente político e democrático, [...] repõe em outros termos uma certa tradição [...] [segundo a qual] se as prioridades estatais não podem ser definidas com base em interesses organizados [...], então aquelas prioridades se devem arquitetar nos gabinetes da tecnocracia estatal por homens esclarecidos (economistas), [supostamente] capazes de dar voz a interesses 'que não se podem fazer representar'. [...]

\footnotetext{
${ }^{10}$ Com efeito, esta "carta aberta" traduz para um público mais amplo a ideia sustentada em "Quanto melhor, melhor": "O chamado Acordo das Montadoras não é outro raio em dia de céu azul. [...] Nele, deu-se o reconhecimento das diferenças e das capacidades de negociação [...] [O] acordo certamente não será a salvação da lavoura. [...] Há razões, sim, para uma aposta" (Oliveira et al., 1993, pp. 3-7).
} 
Esse viés argumentativo é francamente autoritário, e deixa na sombra o que há de mais importante no advento das câmaras setoriais, que é, de um lado, a construção pactuada de esferas públicas onde interesses divergentes possam ser negociados com alguma transparência; de outro lado, a disposição apresentada por capital e trabalho em reconhecer um ao outro na integridade de seus direitos. [...] Está em operação aqui algo que se poderia nomear 'antagonismo convergente' numa esfera pública regulada por normas pactadas pelas partes em conflito. Esta matriz é uma novidade no calendário político nacional e traz consequências que nossos economistas estão longe de ver. $[\ldots]$

Trata-se da definição de regras claras, onde atores dotados de interesses sirvam de medida uns aos outros, publicizando o conflito" (Oliveira, 1993a).

260 Mesmo na seara das relações entre capital e trabalho, o pano de fundo dessa passagem está marcado pela ênfase na publicização do conflito e no "antagonismo convergente". Como ficaria explicitado posteriormente, ${ }^{11}$ esse diagrama de leitura não está apenas direcionado contra uma visão decisionista de mundo, a que Oliveira denomina de "francamente autoritária”. Ele está também debatendo contra outras perspectivas marxistas que não queriam ver na “disposição apresentada por capital e trabalho" uma "novidade no calendário político nacional”, se quisermos, uma potencialidade. A ênfase na publicidade implicada na ideia de "construção pactuada de esferas públicas" de Chico de Oliveira ressoa fortemente em algumas das análises de Paoli e encontra eco também em Telles. Ao se voltarem para a relação entre movimentos sociais e o Estado, por exemplo, Paoli e os autores a ela afins não vêem aí

${ }^{11}$ Veja Oliveira (1999, p. 75). 
“cooptação, mas sim a construção de espaços públicos cuja estruturação se dá pela construção de referências comuns de justiça e de responsabilidade coletiva" (Paoli, 1995, pp. 47-48 - grifos nossos).

O otimismo característico no tom dessas análises ganha vazão através de marcadores que, a exemplo da simples noção de "construção", enfatizam a capacidade ativa dos atores nesse processo. Em "Notas sobre as (difíceis) relações entre pobreza, direitos e democracia”, Telles afirma que

“em meio a essa espécie de síndrome do fracasso [...]

existem sinais e acontecimentos que apontam nessa outra direção. [A saber,] são práticas [...] que reatualizam a ‘invenção democrática' que caracterizou os anos 80” (1994, p. 231).

Os exemplos levantados de forma positivada pela autora - que vão desde a "esfera do trabalho" até o "terreno das lutas populares e das reivindicações urbanas" - atestam, não apenas os "registros de uma sociedade civil emergente", mas, sobretudo, sua

"potência simbólica pela qual a própria realidade é reinventada [...], estabelecendo regras de reciprocidades esperadas e os termos como interesses se representam, a interlocução se estabelece e os conflitos se expressam" (Telles, 1994, p. 233).

A afinidade intelectual entre Vera Telles e Chico de Oliveira transparece no uso de dispositivos cognitivos paralelos e correlatos: se, nele, é enfatizada a disposição para negociar com um outro antagônico, com o correspondente reconhecimento de seus direitos, nela, "interlocução" e "conflito" 
são os índices que conformam a base política sobre a qual são posicionados, ativamente, os atores sociais e suas lutas. Além disso, esse texto também faz alusão à ideia de "construção de referências", entendida como vetor potencial dentro de um processo hegemônico, por meio das noções de "nova contratualidade" e de "construção de parâmetros públicos". Para a autora:

“[o] que parece estar em jogo é a possibilidade de uma nova contratualidade que construa uma medida de equidade e as regras da civilidade nas relações sociais. E isso está dependendo de espaços públicos por onde interesses possam se fazer representar, ganhar visibilidade e legitimidade nas razões e valores que lhes conferem validade, permitindo, no cruzamento dos conflitos que expressam, a construção de parâmetros públicos que reinventem a política no reconhecimento de direitos como medida de negociação e deliberação de políticas que afetam a vida de todos" (Telles, 1994, p. 231 - todos os grifos no original).

Essa "nova contratualidade", embora em registro distinto daquele enfatizado por Paoli, aponta para a possibilidade (historicamente inédita) de um arranjo e de uma articulação entre forças e atores sociais orientados para a um "contrato social, sempre renovado e reinventado":

"um contrato que se estrutura num equilíbrio incerto em torno de uma medida de equidade a ser construída, reconstruída e sempre negociada entre as diferenças, tensões e antagonismos de interesses, valores e aspirações" (Telles, 1994, p. 233).

A noção de "nova contratualidade" cumpre, em positivo, uma função empírico-descritiva na medida em que con- 
juga textualmente ambiguidade e potencial de transformação social sob a expressão "equilíbrio incerto". Ou seja, se a autora não celebra sem mais os movimentos sociais, ela também não deixa de apontar o significado político mais amplo implicado na sua performance e nas experiências deles advindas:

"por maiores que sejam suas ambivalências e contradições, limites e fraquezas, essas experiências renovam - e isso não é pouco - o pensamento e a imaginação políticas, pelos horizontes que descortinam para a invenção histórica"(Telles, 1994, p. 233).

Essa afirmação deve ser entendida no campo político-intelectual no qual ela é forjada: da mesma forma que Chico de Oliveira dialogava com e contra algumas posturas marxistas incapazes de ver a "novidade" implicada no acordo das montadoras, Telles se volta contra as interpretações poliárquicas de democracia e de cidadania que giram em falso ao redor de nossa cultura pré-cívica, "predatória" e "de predadores", 12 do monstruoso híbrido brasileiro. Em direção oposta, a chave interpretativa de Telles se nutre das referências produzidas e veiculadas em experiências que abriam portas para uma política baseada na "visibilidade dos conflitos" e na "construção de critérios de validade e legitimidade dos interesses e aspirações defendidos como direitos" (Telles, 1994, p. 234).

Por outro lado, ainda que sem a formação institucional ao redor daquilo que alguns anos depois se tornaria o Cenedic, a noção de "nova contratualidade" permite perceber o peso e a força das trocas intelectuais entre Maria Celia Paoli, Chico de Oliveira e Vera Telles. "Esse tipo de contratualidade", diz Chico de Oliveira em outra parte,

\footnotetext{
${ }^{12}$ Veja Santos (1993, p. 114).
} 
"é a prova dos nove da possibilidade de democratização, que não é o reino angelical da igualdade, mas parte precisamente do seu oposto para tentar radicalizar as próprias promessas da democracia" (Oliveira, 1994a, p. 15.).

De forma sub-reptícia, como que desempenhando uma sorte de função normativa, fica implícita à noção de "nova contratualidade" a aposta feita por todo um grupo de intelectuais na construção hegemônica que o início da década de 1990 parecia oferecer. Para utilizar alguns dos termos destes autores, diria que até então eles apostavam em um "horizonte" que, embora "incerto", continha em si mesmo os germes potenciais de uma transformação "a ser construída, negociada”, de forma coletiva e pública. Essa foi uma aposta sempre crítica, concentrada na conflitualidade e na publicidade das experiências em curso.

É exatamente para este sentido que aponta Francisco 264 de Oliveira em seu diálogo intitulado "Estado, sociedade, movimentos sociais e políticas públicas no limiar do século XXI", de 1994. Ao abordar o movimento democratizante impelido pela performance de atores da sociedade civil, o autor se utiliza da noção gramsciana de "sociedade política" para pensar

“[nos] termos da transformação da representação desses atores e da construção de uma esfera pública. [...] meu argumento é de que esse movimento de democratização nas bases da sociedade tem muitas virtualidades e cabe a nós explorá-las". (Oliveira, 1994b, p. 6).

Segundo o autor, tais "virtualidades" se expressariam basicamente em quatro eixos: no rearranjo da cena política tradicional e de seus discursos; na institucionalização de demandas societais sob a forma de políticas públicas; na capacidade de negociar conflitos entre atores estrutural- 
mente desiguais (a exemplo das Câmaras Setoriais); e, por fim, na discussão sobre "qual Estado se quer", ou seja, sobre a "capacidade de redesenhá-lo, redefini-lo e formatá-lo de um jeito diferente" (Oliveira, 1994b, pp. 11-13). Ao longo da reflexão acerca das duas últimas "virtualidades", é possível encontrar paralelos significativos em relação àquilo que Paoli designou como "construção entre forças conflitantes", na medida em que

"[tal] virtualidade não é para anular os conflitos, não é para instaurar a harmonia nem o reino dos anjos. É para reafirmar os interesses de cada um. Não é o acaso nem o mercado que resolvem. O que resolve são atores estrategicamente colocados que, a partir de seus próprios interesses, moldam ou tentem moldar uma política macroeconômica" (Oliveira, 1994b, p. 13).

Essa passagem sintetiza de forma exemplar uma postura interpretativa que via nas formas e espaços de organização ativa e, sobretudo, de participação conflitiva de atores econômicos, um vetor fundamental no sentido mesmo da construção democrático-hegemônica. "E esse processo de democratização é, ao meu ver, o que está de fato construindo essa esfera pública no Brasil” (Oliveira, 1994b, p. 15).

Para finalizar este subitem sobre os anos 1990, remeto-me a "Direitos Sociais: afinal do que se trata?", de Telles (1998), para, em seguida, passar a uma discussão abreviada sobre a concepção de cidadania que a aproxima da reflexão de Paoli. "Direitos Sociais" interessa particularmente por duas razões: o texto apresenta a primeira reflexão na qual a influência de Jacques Rancière se torna central no argumento da autora e também porque, aqui, já marcada por aquela influência teórica, a noção de política passa a ser radicalizada, somando ao "conflito" e à "interlocução" a noção de "dissenso". Iniciando sua reflexão sobre os "direi- 
tos sociais", Telles recorre às definições clássicas desse tipo específico de direito:

"direito ao trabalho, direito ao salário igual por trabalho igual, direito à previdência social em caso de doença, velhice, morte do arrimo de família e desemprego involuntário, direito a uma renda condizente com uma vida digna, direito ao repouso e ao lazer [...] e o direito à educação"(Telles, 1998, p. 36).

A julgar pela sua concepção clássica euro-americana, a discussão sobre direitos sociais no contexto brasileiro, bem afirma a autora, ou leva à constatação de sua inexistência histórica, ou leva a se fixar na fragilidade e na perda dos parcos direitos aqui conquistados. Telles recusa essas duas saídas, que vê como um "risco de demissão do pensamento", e trata de "tomar os direitos sociais como cifra pela 266 qual problematizar os tempos”(Telles, 1998, p. 37). Esse texto vai, então, procurar "o sentido político inscrito nos direitos sociais”(Telles, 1998, p. 38). É nessa procura textual que é possível encontrar outra noção de política, uma política rancieriana. Para falar dos direitos sociais, Telles se volta para aquilo que ela denomina de "sujeitos falantes": "esses personagens [que] comparecem na cena política como sujeitos portadores de uma palavra que exige seu reconhecimento"(Telles, 1998, p. 39).

Exemplos de "sujeitos falantes" são, por exemplo, o movimento negro e o movimento dos trabalhadores sem-terra. Já, o seu recurso político é a "palavra", que diz o justo e o injusto, palavra pela qual tais sujeitos "se nomeiam e dão nome ao mundo", ${ }^{13}$ exigem o "reconhecimento de sua (forte) alteridade política" e "sua capacidade de interlocução pública".

\footnotetext{
${ }^{13}$ Note-se que Paoli, em seu texto sobre o "estatuto político" dos movimentos sociais, já acenava para essa ideia de "nomear o que é a política".
} 
Cada vez mais, o espaço da prática política é descrito em termos relacionais e comunicativos, entretanto, em sentido radicalmente não-habermasiano. A presença dos "sujeitos falantes" na cena política, isto é, o reconhecimento público da palavra desses sujeitos não é fundado em um espaço no qual a regra é o estabelecimento de consensos. Em movimento precisamente inverso a esse, importa na conformação do espaço público a "dimensão transgressora" que leva à produção do "dissenso":

"um dissenso sobre o que conta e deve ser levado em conta no mundo comum da política, sobre quem fala e quem tem ou não a prerrogativa da palavra, sobre a pertinência ou não pertinência das questões e realidades nomeadas por essa palavra"(Telles, 1998, p. 41).

Assim, Telles associa a presença desses sujeitos falantes na cena política ao questionamento dos princípios universais da cidadania, "colocando tais princípios à prova”. Em plano analítico, dissenso, interlocução e palavra são os marcadores que conformam a política, ou seja, o "terreno do conflito" - "construído pelas questões e temas em torno dos quais o conflito se arma, e a divergência e a polêmica se estruturam" (Telles, 1998, pp. 40-41). A meu ver, tal disposição analítica tem implicações maiores e normativamente positivas no âmbito explicativo. Exemplo claro dessa implicação pode ser notado, por exemplo, na utilização da ideia de "sujeitos falantes", na medida em que é precisamente a partir de tal noção que o potencial do "reconhecimento da alteridade" e da "conflitualidade" pode ser reconhecido como tal. Obviamente, essa compreensão não obsta a crítica, por exemplo, às graves formas de desrespeito contra as diferenças em um contexto social como o brasileiro. Pelo contrário, por tensionarem o exercício crítico, estas categorias permitem adentrar com maior profundidade 
nas tensões inerentes ao processo histórico e à função dos atores sociais dentro dele. Parece-me que uma noção como a de "sujeitos falantes" permite a complexificação no nível da própria explicação. Isso se deve, em grande medida, à concepção de "política" que subjaz a ela e, também, lhe dá sentido e inteligibilidade heurística.

Mas, afinal e em suma, qual é a concepção intertextual de política subjacente às aproximações e afinidades entre Paoli, Oliveira e Telles, nos anos 1990? Trata-se de uma "política" que gira necessariamente em torno do caráter conflituoso e contraditório da estrutura social brasileira. Como já observamos, essa compreensão se dá de forma muito específica, e com diferentes ênfases, na argumentação de cada um deles. Entretanto, como pretendia demonstrar, à medida que posicionavam ao mesmo tempo a conflitualidade, a legitimidade e a publicidade dos conflitos no centro da crítica, suas produções teóricas permi268 tiram pensar ou, na pior das hipóteses, apenas imaginar um horizonte de prática política (para falar nos termos de Paoli) que conferia "legitimidade aos conflitos na esfera da sociedade brasileira" e (como vimos com Telles) "isso não é pouco". Assim, o início e boa parte da década de 1990 foram marcados por uma "possibilidade política", vale dizer, pela possibilidade de uma cena política "a ser construída”, de forma dissensual, pública e coletiva. Aquela década conformaria, essa era a aposta, um cenário positivo no qual a "invenção democrática” dos anos 1980 seria "alargada” ou, até mesmo, radicalizada. No campo da política, esse "campo de práticas legítimas de invenção, conflito e negociação", a palavra de "sujeitos falantes" teria (ou, de fato, teve?) uma dimensão transgressora, um potencial simbólico até então desconhecido na história brasileira. Em linhas gerais, foi essa a concepção de política que dava sustentação ao projeto teórico-normativo deste grupo de autores. Como veremos mais adiante, aos olhos deste gru- 
po de autores, a década de 1990 não cumpriu suas promessas democrático-politizadoras e, ao frustrar os germes de transformação social dos 1980, "anulou" ou "aniquilou" a política e, com ela, a história.

\section{A cidadania como "construção" e como dilema}

A concepção de cidadania veiculada pela produção de Paoli e de Telles, durante a década de 1990, só pode ser compreendida nos termos da "política" tal como acima descrita. A cidadania é posicionada, repetidas vezes, dentro daquele campo estruturado por conflito e interlocução, mas diferentemente do "dissenso", não chega a constituir um índice normativo de tal campo. Quer dizer, muito mais que um índice forte, essa noção aparece como um dilema social indissociável de outros dilemas, nomeadamente, direitos, trabalho e pobreza. Desta forma, embora não ocupe posição central nos argumentos daquelas autoras, a cidadania como que constitui um subespaço "a ser construído”, em um horizonte cujos referenciais são a construção hegemônica e a possibilidade da política, pelos diversos atores sociais.

É neste sentido que Paoli, ao tratar da memória como espaço de luta política, fala da "cidadania":

"se por esta palavra entendermos a formação, informação

e participação múltiplas na construção da cultura, da política, de um espaço e de um tempo coletivos" (Paoli, 1992, p. 26).

Neste sucinto e exemplar texto, a autora enfatiza a necessidade de:

"fazer com que experiências silenciadas, suprimidas ou privatizadas da população se reencontrem com a dimensão histórica" (Paoli, 1992, p. 27). 
Não se trata, contudo, de uma mera produção de "novos heróis" a serem historiografados ou de somar "novas mitologias" à história oficial. Pelo contrário, para a autora, a produção cidadã da história:

"trabalha em torno da disputa pela memória social, que constantemente desmonta os mecanismos de institucionalização do significado que a sociedade constrói a respeito de si mesma - de seus cidadãos, de suas diferenças, de suas identidades e de suas desigualdades.

O reconhecimento do direito ao passado está, portanto, ligado intrinsecamente ao significado presente da generalização da cidadania, por uma sociedade que evitou até agora fazer emergir o conflito e a criatividade como critérios para a consciência de um passado comum" (Paoli, 1992, p. 27 grifos nossos).

Ao mesmo tempo que torna explícita a forma política inerente à construção do passado, ${ }^{14}$ Paoli recorre àquela concepção conflituosa de política e, mais uma vez, fornece pistas da aposta de que, subentendida como construção e como disputa, a cidadania poderia, então, se generalizar.

Na produção de Telles, as referências a tal noção estão frequentemente sem uma qualificação categorial do que a autora entende por "cidadania". De nenhuma forma isso macula sua reflexão, pois, em "Pobreza e Cidadania", com ensaios elaborados entre 1996 e 99, a discussão levantada sai de termos formais para inquirir historicamente os limites e dilemas da produção de laços cidadãos. Em "Os sentidos

\footnotetext{
${ }^{14}$ Cabe aqui visualizar uma conexão intertextual que aproxima este texto sobre o "direito ao passado" àquele dos "Direitos sociais", de Telles. Tal conexão pode ser entrevista quando esta autora afirma que os "sujeitos falantes" "põem em foco, e sob o foco do debate, diferentes modos de descrever o país em sua história e tradições" e que a "palavra" de tais sujeitos "tem também o poder de tornar possíveis e relevantes coisas que antes não existiam em nosso horizonte cognitivo e valorativo" (Telles, 1998, p. 42).
} 
da destituição", ao destrinchar as relações entre "cidadania, civilidade e civismo" (Telles, 2001, pp. 62-78), muito embora a discussão se volte de forma mais enfática para os dois últimos termos, é possível encontrar uma concepção análoga a de cidadania entendida como

"prática que faz apelo a valores publicamente reconhecidos e que aposta na existência de uma ordem legal capaz de garantir as reciprocidades que a noção de igualdade supõe" (Telles, 2001, p. 77).

Nesta breve definição, a intenção da autora parece estar voltada para as defasagens entre o "Brasil real" e o "Brasil legal”, em meio às quais a própria cidadania poderia ser situada como instância de mediação civilizatória entre essas duas realidades.

Já em seu texto sobre as "difíceis relações" entre pobreza e democracia, em registro próximo ao de Paoli, Telles explicita o laço entre o dilema social da cidadania e a "questão dos direitos", ou da falta deles, e, por essa via, permite visualizar o otimismo do e no horizonte dos anos 1990. Diz ela:

"se a pobreza é questão de direitos e conquista da cidadania, o que parece estar em jogo hoje é a possibilidade de que, nesse país, se dê a construção democrática de uma noção de bem público, de interesse público e de responsabilidade pública que tenham como medida os direitos de todos" (Telles, 1994, p. 226 grifos nossos).

Mais uma vez, a reflexão aparece estruturada pela política como possibilidade real histórica e, de outro lado, por este dilema social, pela cidadania ativa e publicamente construída e conquistada.

Como veremos a seguir as concepções de cidadania e de política - na acepção aqui descrita, respectivamente, 
como construção/dilema e como possibilidade/conflito -, no bojo da "nossa contra-revolução", para usar os termos de Chico de Oliveira, "dançaram". ${ }^{15}$

\section{Duas inflexões, uma "perplexidade"}

A despeito desse grupo de evidências histórico-políticas que compunham um horizonte democraticamente promissor para a realidade brasileira, o desenrolar histórico nacional e, sobretudo, internacional frustrou a expectativa de todo o grupo de intelectuais dentro do Cenedic e ao redor dele. Uma das primeiras referências textuais aos "limites" - que se tornaram, no decorrer da primeira década do século XXI, para estes autores, uma única e taxativa impossibilidade da cidadania e, especialmente, da prática política pode ser encontrada em "Os Sentidos da democracia", de Oliveira e Paoli (1999). Os termos pelos quais Paoli descreve a situação social brasileira deixam claro que não se tratava mais de

272 falar em política como possibilidade de construção democrático-hegemônica: a "inevitável privatização", as "misérias do presente", a "expansão mundializada do capital", o "silenciamento da política", são todos índices que atestam uma mudança ocorrida e aprofundada na década de 1990 - aquela mesma que, na esteira dos anos 1980, prometeu algum dia a possibilidade (sempre "incerta" e "instável") de construção cidadã.

Este tom pode ser também encontrado em "A Cidade e o trabalho", de Telles (2001). Em linhas gerais, a reflexão aponta para a ideia de que o "poder estruturante do Estado”, devido à "economia globalizada” e suas exigências de "reestruturação produtiva”, não dava conta de questões sociais como a pobreza, conseguindo, no máximo, fazer uma "gestão pragmática" com "programas sociais compen-

${ }^{15}$ Veja Oliveira (2006, p. 274). 
satórios”. Aqui, é notória a mudança ocorrida no tom da abordagem, pois, diferentemente de antes, ${ }^{16}$

"o fato é que estamos face a um debate público em grande parte tomado por uma espécie de afirmação ritualística ou protocolar da exigência ética da cidadania" (Telles, 2001, p. 34).

O que aparece a partir do fim da década de 1990 é uma "perplexidade", termo de Paoli (1999, p. 10), tanto mais desencantada quanto mais profunda. Então reunidos em função de um seminário internacional que marcaria a primeira formação institucional do Cenedic, os autores, tal como sintetiza Paoli, estavam perplexos com "uma forma de poder moderno que parece desistir" de

"um mundo comum referenciado a parâmetros cidadãos, dentro dos quais se desenhavam os caminhos do conflito, das negociações, dos horizontes futuros" (1999, p. 10).

Note-se, entretanto, que se o tom da abordagem parece pessimista, se comparado ao otimismo de boa parte da década de 1990, ele é radicalizado após as reflexões de $O$ Ornitorrinco, e, posteriormente, como que se cristaliza em “A era da indeterminação". No detalhe: ao fim da década passada ainda era possível, mesmo dentro de um discurso notadamente marcado pelo seu tom desiludido, pensar e falar em "alternativas" "para recuperar os direitos de uma cidadania que, reinventando a si própria pela discordância e pela sua própria recriação, possa reinventar novos caminhos da construção democrática” (Paoli, 1999, p. 10).

\footnotetext{
${ }^{16}$ Esse "antes", como tentei demonstrar, tinha decididamente outro "horizonte": "É nesse horizonte de problemas que a questão da pobreza atual se coloca como problema propriamente político de invenção e pactuação das regras da vida social" (Telles, 1994, p. 229).
} 
Havia, pois, espaço para um "resgate", uma "reinvenção", cujo espaço de realização possível ainda era aquele da política dissensual, discordante, dissonante. O lugar ocupado pelo "conflito", por exemplo, era ainda um parâmetro de discussão:

"[O] título do seminário [do Cenedic] foi um convite para os autores refletirem sobre os processos atuais de construção de uma economia mundializada e o conflito que é travado, em seu interior, pelo sentido da democracia"(Paoli, 1999, pp. 10-11).

Paulatinamente, no entanto, esse espaço possível da política de acepção gramsci-rancieriana fica cada vez mais esvaziado, desmontado, desativado, para tornar-se, então, francamente impossível. Neste sentido, cabe notar que o esforço de elencar categorias e adjetivos de natureza geralmente negativa para dar conta da complexidade sociopolítica brasileira, não apenas permeia e articula as diferentes posições daquele conjunto de intelectuais, como também tem sua expressão mais evidente na recente produção de Telles.

Nos primeiros textos de Telles, já marcados pela inflexão e pela "perplexidade", aparece a ideia de "uma dificuldade [...] na construção de parâmetros críticos para ordenar a descrição e problematização da situação social brasileira" (2001, p. 35). Todavia, em pouco tempo, a "construção de parâmetros" deixa de ser uma "dificuldade" para, então, francamente perder seu sentido: ${ }^{17}$

\footnotetext{
${ }^{17}$ São vários os textos, entre 2001 e 2007 , nos quais Telles repete de diferentes formas, mas sempre com ênfase notória, tal perda de sentido, a saber, a incapacidade cognitiva e categorial para (não mais) explicar as transformações sociais. Tal incapacidade, entretanto, é generalizada e levada pela autora a um ponto taxativo: "já é lugar comum dizer que nossas teorias e categorias de análise não dão conta das novas realidades" (Telles, 2007b, p. 504).
} 
“[As] noções de leis, direitos, cidadania e espaço público foram esvaziadas de sua potência crítica. Melhor dizendo: foi esvaziado o espaço conceitual em que essas noções se compunham [...]. Desativado (ou deslocado?) o plano da consistência em que essas noções circulavam e fincavam pontos de referência, elas [as noções] ficam desprovidas da potência de se confrontar com uma realidade que escapa e transborda por todos os lados. Ficam girando no vazio" (Telles, 2007a, pp. 201-202 - grifos nossos).

Esse conjunto de passagens permite entrever duas inflexões: no plano propriamente analítico, a exemplo do "uso ritualístico" da cidadania e dos direitos, as noções (todas elas?) já não são mais dotadas de "potência crítica" e tampouco dão conta das "realidades em mutação" - expressão de Telles. Como veremos ao final do texto, subjaz à inflexão interna ao sentido das noções elaboradas e empregadas pelos autores do Cenedic uma concepção de política cujo referencial teóriconormativo pode ser precisamente designado por concepção da "não Política". Em plano externo, transcorre aguda inflexão na própria realidade histórica que agora parece "escapar e transbordar" de forma ininteligível e, principalmente, inelutável. Quer dizer, o tom dado externamente pela mundialização do capital tem efeitos diretos sobre as orientações socioeconômicas assumidas pela democracia brasileira ao fim e após a década de 1990. Apesar da divisão interno-externo ter apenas um fim didático, a visualização do duplo nível de tais inflexões permite melhor destrinchar as bases do cenário que em dado momento ruiu e, por isso mesmo, causou tamanha "perplexidade" neste grupo de autores. É desse cenário em ruínas que trata em grandes linhas o próximo tópico.

\section{Em cena, neoliberalismo e a "dominação globalizada"}

Para boa parte dos autores do Cenedic, falar da recente transformação das questões sociais significa falar das trans- 
formações ocorridas no mundo do trabalho e dos novos arranjos da esfera produtiva. Neste sentido, já na primeira metade da década de 1990, Telles observava que

"[a] reestruturação industrial, as mudanças no padrão tecnológico, as transformações na composição do mercado e as tendências já visíveis de flexibilização e precarização do trabalho redefinem a questão social" (Telles, 1994, p. 230).

Essas "tendências já visíveis" configuram as bases de um cenário no qual o tom predominante nas políticas de Estado e nas novas formas de organização do trabalho foi dado pelos "ajustes" neoliberais, suas práticas e projetos, e pela "mundialização do capital”, termo de Chesnais, equivocadamente denominada globalização. No âmbito das orientações políticas neoliberais, o governo FHC “aprofundou, num grau insuspeitado, o desmanche iniciado [por 276 Collor]" (Oliveira, 2003a, p. 202). Grosso modo, três processos paralelos e correlacionados redesenharam durante os anos 1990 o jogo de linhas de força e a configuração mais ampla nos quais se relacionavam e disputavam diferentes instituições e atores brasileiros: i) privatização, entendida como processo de desestatização e/ou retirada de empresas e serviços públicos nacionais; ii) desregulamentação jurídica e também cotidiana do trabalho; e, por fim, iii) a abertura ampla e irresponsável ao capital estrangeiro. ${ }^{18}$ Somado a esse tripé, operam outros processos no bojo da "mundialização do capital”, que, a exemplo da digitalização, da molecularização e da financeirização do capitalismo, mais uma

\footnotetext{
${ }^{18}$ Para esboçar de forma muito sucinta esse cenário me utilizo do arcabouço de Oliveira 1999, 2003. Em tempo, cabe notar que "Política numa era de indeterminação: opacidade e reencantamento" foi primeiramente publicado em "República, liberalismo e cidadania", de 2003. Algo modificado, sempre e cada vez mais desencantado, este texto foi republicado com o título "A dominação globalizada" em 2006 e abre a organização de "A era da indeterminação", de 2007.
} 
vez colocam em desvantagem a posição do Brasil na divisão internacional do trabalho e na concorrência globalizada.

Embora a sucinta descrição desse tripé neoliberal não dê conta da complexidade dos processos socioeconômicos transcorridos nos anos 1990, ela permite situar, ainda que em grandes linhas, as bases do cenário "desmanchado" e desencantador da aposta nas "invenções democráticas" da década anterior. Voltando à produção de Telles e de Paoli, é possível afirmar que o par privatização/desregulamentação foi aquele cujos efeitos sobre a luta em torno da produção de direitos e de cidadania foram diagnosticados como mais perversos e graves.

Como observado anteriormente, Telles problematiza em "A Cidade e o trabalho" a incapacidade e a retirada do Estado no sentido de regular e de regulamentar as condições de vida urbana (no duplo sentido do adjetivo "urbano") e os padrões de sociabilidade. Em um contexto marcado pelo ataque neoliberal à (suposta) ineficiência e disfuncionalidade estatal,

"[o] Estado deixa de ser referência ou o agente de um projeto de integração nacional que, mito ou realidade, fazia a associação entre interesses nacionais, empresas estatais e serviços públicos"(2001, p. 36).

Portanto, em face do discurso insidioso que defende a "desnecessidade do público" e que trata a pobreza e os "excluídos" como "problema técnico", a crítica de Telles desvela de forma contundente a base discursiva do projeto neoliberal e sua versão mercadológica de modernidade.

Também Paoli aponta para este sentido em sua reflexão acerca das relações entre cidadania e "solidariedade social empresarial” (2002, p. 379). Para além do ataque, sempre crítico e necessário, aos laços entre "autodesresponsabilização estatal", "filantropização da cidadania" e "descontratualiza- 
ção do social", a autora sublinha que as iniciativas "sociais" do empresariado encerram "potencial inovador" e "podem ser uma experiência social e humanitária relevante diante das prementes necessidades e carências da população pobre brasileira"; se tais iniciativas podem ser "relevantes", elas não podem, contudo, prescindir das "ambiguidades e ambivalências" constitutivas de sua relação seja com o Estado, seja com seus trabalhadores, seja ainda com os projetos políticos a elas concorrentes (Paoli, 2002, pp. 404-414). É nesse jogo de relações que a análise de Paoli permite vislumbrar o campo "do social" no qual o empresariado disputa legitimidade, bem como a significação sociológica "ambígua" ${ }^{19}$ das "ações sociais empresariais" atualizadoras de significados despolitizados e despolitizantes de cidadania.

Desnecessário dizer que o jogo de relações a respeito do qual Paoli trata está definitivamente atravessado pelo "totalitarismo neoliberal" de que nos fala, em outro momento,

278 Chico de Oliveira. ${ }^{20}$ A referência a essas reflexões de Telles e de Paoli serve para lembrar que a compreensão da luta contemporânea, por exemplo, em torno da cidadania passa pela compreensão daquele tripé mundialmente operante. Serve, além disso, para mostrar como discurso e agenda neoliberais tiveram efeitos inegáveis e perversos sobre a vida pública brasileira e sobre os sentidos de sua democracia. Seguramente, não está no escopo deste texto verificar como ou em que medida tal projeto concorreu com ou suprimiu projetos alternativos (projetos contra-hegemônicos, diria Paoli) de sociedade, de cidadania, de política... Proponho, no entanto, como conclusão, defender a ideia de que a pro-

\footnotetext{
${ }^{19}$ Vale sublinhar que Paoli, utilizando-se também dessa ideia de "ambiguidade", faz a leitura do papel político dos direitos trabalhistas na era Vargas. Diz ela: "[A] natureza ambígua dos direitos promovidos pelo Estado [varguista] [...] mostra uma experiência política de integração social cujo espaço é feito de práticas múltiplas, que continuam vivas apesar de o espetáculo estatal ter aparecido como ato único" (Paoli, 1989, p. 6 - grifos nossos).

${ }^{20}$ Veja Oliveira (1999).
} 
gramática neoliberal não operou de forma exclusiva no sentido de desencantar a aposta dos intelectuais do Cenedic nas capacidades civilizadoras dos 1990. Essa hipótese ganha tanto mais sentido se nos voltarmos àquela inflexão analítica da qual falávamos antes, bem como à concepção de "não política" a ela subjacente.

\section{Recusa, "ilusão" e negação: da aposta à perplexidade}

Antes de prosseguir, um retrospecto: afirmei, primeiramente, que o debate acadêmico a respeito dos rumos da democratização brasileira teve na performance dos movimentos sociais, novos e velhos, uma de suas principais referências. A qualificação político-normativa da tal performance variava de acordo com a postura interpretativa bastante ligada ao nível político-ideológico do ou da intérprete. Além disso, a interpretação do significado social (mais, ou menos, amplo) dos movimentos no sentido assumido pela construção democrática variou em função da concepção de "política" subjacente às diversas e divergentes posturas interpretativas. Partindo daí, vimos como as reflexões de Oliveira, Paoli e Telles trazem marcas intertextuais, implícitas ou explícitas, que dão acesso a noções de "política" e de "cidadania".

Expressos através de noções como "antagonismo convergente" e "nova contratualidade", conflitualidade e interlocução apareceram então como os principais índices na conformação daquilo que esses textos designavam como prática e espaço da política - aquele "campo de práticas legítimas de invenção, conflito e negociação”. Em certa medida, ao considerarmos sua orientação ideológica e de seus interlocutores mais próximos, dizer que elas enfatizavam a "legitimidade do conflito" se torna algo óbvio. O que o conjunto de textos permitiu entrever, isso sim, foi uma quase confusão, uma espécie de não divisão, entre suas constatações empíricas e a aposta feita nessas mesmas constatações. Os exemplos fornecidos e analisados se mostraram 
permeados por um misto de verificação e aposta, orientado pela possibilidade histórica de construção democrático-hegemônica no Brasil e por seus dilemas, tal como a cidadania, "a serem" construídos, explicitados, negociados. Assim, até meados dos anos 1990, a produção teórica desse grupo de intelectuais veicula um otimismo cujas raízes podem ser situadas nas várias experiências nas quais os conflitos de interesses ganhavam expressão pública, e, como veremos ao final do texto, na oposição em relação àquelas posturas que viam a ênfase teórica nas formas e expressões populares de associativismo como mero "basismo",

A partir de "Os Sentidos da democracia", de 1999, uma inflexão aguda e perplexa passa a operar no tom da abordagem e nas categorias utilizadas para descrever as "mutações" em curso - apenas para descrever, diga-se de passagem, sem precisar ou pretender explicar, dado que ("já é lugar comum dizer") ${ }^{21}$ as categorias não davam mais conta dessa

280 novíssima realidade. No turbilhão das transformações mais amplas pelas quais passou o Brasil durante a década de desmanche neoliberal, ocorreu uma guinada que sintetiza aquela "perplexidade" e, indiretamente, leva a uma dupla recusa, sociológica e utópica, particularmente mais clara na orientação assumida pelo último projeto intelectual de Telles.

"Pois bem, vinte anos depois", nos diz esta autora, "ao que parece, no lugar de Claude Lefort, é Giorgio Agambem [...] que parece dar a pauta e acusar a virada dos tempos [...]. Estado de exceção e vida nua são noções que compõem um espaço conceitual que circunscreve outra ordem de problemas" (2007a, p. 200). ${ }^{22}$

\footnotetext{
${ }^{21}$ Segundo Telles (2007b, p. 504).

${ }^{22}$ E prossegue ela: "Entre Claude Lefort e Giorgio Agambem há mais do que ventos mutantes dos modismos intelectuais. Há de se refletir sobre o que se passa entre os dois registros [...]. A discussão poderia ir longe, mas isso ficará para um outro momento. [...] Pois, entre um e outro, quer dizer, nos vinte anos que sepa-
} 
Diria, antes, que no lugar da aposta é a perplexidade que parece dar a pauta. Aliás, nessa "virada dos tempos", fica difícil falar até mesmo em "pauta” porque, junto da demissão das categorias que tentavam explicar o real, que agora escapa, escorrega, foge e transborda, também os "quadros de referências" e os horizontes são limitados, estão encolhidos:

"Se antes as questões urbanas eram definidas sob a perspectiva (e promessa) do progresso, da mudança social e desenvolvimento (anos 60/70) e, depois, da construção democrática e dos direitos sociais como cifra de uma modernidade pretendida como projeto (anos 80 ), agora os horizontes estão mais encolhidos, o debate em grande parte é conjugado no presente imediato das urgências do momento [...]" (Telles e Cabanes, 2006, p. 14). ${ }^{23}$

Bastante marcado por aquele desencanto teórico-político, o projeto intelectual de "Nas tramas da cidade" explora uma série de crises e de deslocamentos justapostos: crise da organização e distribuição do espaço urbano, de violência e de sociabilidades nesse espaço e, em especial, a crise na capacidade cognitivo-explicativa de dar conta dele. Uma das primeiras menções à crise no quadro de referências já estava presente em "A Cidade e o trabalho". Ali, "imprecisão" e "indefinição" parecem ocupar a base da "fragilidade de referências". Paulatinamente, "dificuldade" e "fragilidade" analíticas foram substituídas pelo exercício da "etnografia experimental". Perante essa novíssima realidade urbana e suas crises, ocorre um redirecionamento da perspectiva

ram dois registros de debate, as noções de leis, direitos, cidadania e espaço público foram esvaziadas de sua potência crítica" (Telles, 2007a, p. 201).

${ }^{23} \mathrm{E}$ prosseguem: "[...], os problemas urbanos tendem a deslizar e a se confundir com a gestão urbana e a pesquisa social parece em grande parte pautada pelos imperativos de um pragmatismo gestionário das políticas sociais voltadas às versões brasileiras dos 'quartiers difficiles'” (Telles e Cabanes, 2006, p. 14). 
de análise, voltada agora para o micro e é sob a influência desse exercício, no qual Telles vê um "parâmetro descritivo”, que suas reflexões apresentam o nível microscópico do "jogo" "de crispações", "de pulsações", da "vida nua" e suas "tramas", dessa "zona de sombra". Dito de outra forma,

"é justamente nessas tramas da cidade que se aloja a complicação atual e que será preciso, por isso mesmo, auscultar. É nessas tramas que os lances da vida são jogados" (Telles e Cabanes, 2006, p. 16).

Enfim, no registro experimental, resta tecer de forma etnográfica os fios crus e violentos dessa trama, tal e qual. A opção por essa renovação na orientação metodológica não carrega em si mesma as máculas que podem ser ou não atribuídas ao método etnográfico. Mais importante que o próprio método, contudo, é a justificativa acionada para sua utilização:

"[o] que antes foi dito sobre a cidade e seus problemas, a 'questão urbana', parece ter sido esvaziado de sua capacidade descritiva e potência crítica em um mundo que fez revirar de alto a baixo o solo social das questões então em debate" (Telles e Cabanes, 2006, p. 13).

Na perspectiva defendida pela autora, trata-se de

"reter a cidade como plano de referência supõe uma estratégia descritiva que escapa aos termos correntes do debate atual, em grande medida polarizado entre a ênfase nos dispositivos transnacionais do assim chamado crime organizado, de um lado, e, de outro, a discussão do que se convencionou chamar de populações em situação de risco social [...]. Entre um e outro, entre fatos e ficções nessas duas pontas do debate atual, há toda uma trama urbana que resta a conhecer" (Telles e Hirata, 2007, p. 176) 
É possível relacionar a "estratégia descritiva" de Telles àquilo que Roberto Schwarz denominou de "atualismo", ${ }^{24}$ isto é, "o privilégio definitório do presente", sorte de "totalização provisória e heurística a qual se pretende ligada ao curso efetivo das coisas" (Schwarz, p. 16) Entretanto, na medida em que se volta para a história minúscula das microcenas, e porquanto permanece colada "ao curso efetivo" da "trama urbana", o atualismo de tal estratégia veicula um tipo de recusa sociológica, no sentido de que ela evita explicitar a forma pela qual a "trama" microscopicamente descrita se insere no quadro social mais amplo dentro do qual ela ganha ou mesmo, se for o caso, perde sentido. Quer dizer, para falar em tom estadunidense, ${ }^{25}$ sua descrição não logra explicitar o link micromacrossocial na sua dialética mesma, nas contradições, ambiguidades e tensões inerentes a essa relação. "Nada além do aqui e agora”, nos termos de Adorno; uma vez restrita à atualidade das "urgências (empiricamente constatadas e descritas) da vida cotidiana", a análise desenvolvida sobre as "tramas da cidade" não explica as formas pelas quais as cenas do microcenário reproduzem, redefinem o macro ou (porque não?) resistem a ele. ${ }^{26} \mathrm{O}$ "atualismo" e a urgência de incivilidade da cidade se travestiram, em teoria, de urgência empirista.

\footnotetext{
${ }^{24}$ Por meio desse termo, Roberto Schwarz faz, em seu "Prefácio com perguntas", um elogio a Chico de Oliveira. "O atualismo reflete uma exigência teórica, bem como a aspiração à efetividade do pensamento, como parte de sua dignidade moderna" (Schwarz, 2003, p. 16).

${ }^{25}$ Veja Alexander (1987).

${ }^{26}$ Adorno mostra de forma contundente a aporia própria ao empirismo que, a despeito de sua disposição eminentemente descritiva e, paradoxalmente, por conta dela, "elimina a experiência". Diz ele: "[o] conceito de fato que já foi discutido em diversas ocasiões e que é idolatrado pela Sociologia vigente tem entre uma de suas características a de ser representado propriamente como atemporal, como momento presente pontual. Quando eu afirmava que o empirismo vigente de modo paradoxal eliminava a experiência, então - se quiserem - aqui encontramos a razão disso, na medida em que essa característica pontual, esse 'isso é o caso' que abstrai de sua historicidade particular, de suas implicações históricas e converte o resultado de um vir-a-ser em um 'ser-deste-modo-e-não-de-outro' absoluto. [...] O que não é nada além de ser 'aqui e agora', endurece ou solidifica justamente mediante essa fixação no instante” (Adorno, 2008, pp. 334-335 - grifos nossos).
} 
Vista de outro ângulo, paralela à denegação de explicação, corre a recusa ou demissão utópica. Isso se expressa especialmente por meio da ideia de que as recentes e violentas transformações sociourbanas teriam solapado o "solo" conceitual e categorial disponível para interpretá-las. Quanto a esse último ponto, apresento a incisiva crítica de Maria Célia Paoli a Anthony Giddens, principal ideólogo da chamada "terceira via":

"como acontece em toda tentativa política de romper com heranças passadas, a tentativa intelectual de ignorá-las só pode passar pela sinonimização abstrata do novo com o puro tempo presente" (2002, p. 383).

Em diferentes e reiterados momentos, aparece a defesa da ideia segundo a qual "[seria] quase trivial dizer que está tudo muito alterado em relação às décadas anteriores" (Tel284 les e Cabanes, 2006, p. 13). Mesmo se endossarmos a ideia segundo a qual "tudo", já e agora, está "muito alterado", para onde quer apontar tal ideia, qual é, enfim, seu sentido? A “dominação globalizada" e a desestruturação por ela impelida são inapeláveis, incontornáveis? Paradoxalmente, resposta possível a tais questões pode ser vista em um belo diagnóstico de Chico de Oliveira: àqueles processos, até fins dos 1990, existiam alternativas. "A inevitabilidade... Qual era o lema do Collor, por exemplo?” - nos lembra Oliveira (2000, p. 24) "[...] era muito parecido com o do Pedro Mallan, o lema do Collor era "vencer ou vencer". [...] É como se diz hoje: "não há alternativa”. Como "não há alternativa?”. Apropriando-me de Oliveira, diria que a "estratégia descritiva", porquanto categorialmente solapada e, ao mesmo tempo, assentada em registro teórico-metodológico cujo pressuposto fixa o presente sob a rubrica do "nada além de ser aqui e agora", descolando-o de qualquer passado histórico ou teórico, leva quase que diretamente a uma espécie de "inevitabilidade". 
Ou seja, na medida em que defende e generaliza o parti pris segundo o qual

“[o] que está em pauta nos tempos que correm é a inviabilidade de nos fixarmos nos termos como até agora lidamos com as coisas do mundo" (Telles, 2007a, p. 200),

esse tipo de postura interpretativa abre mão de qualquer potencial categorial ou normativo para pensar o "mundo das coisas", restando-lhe então os "fios da trama" e ficando refém de um empirismo de cunho microscópico. Se esses "fios" lhe apresentam a pura e crua violência concreta, cabe apenas e inevitavelmente descrevê-la. Desta forma, embora ganhe em riqueza e densidade de dados, lucro que de forma alguma pode ser subestimado, tal postura encerra também um tipo de recusa utópica. Como corolário da recusa sociológica, o afastamento com relação a qualquer horizonte utópico aproxima a perspectiva "perplexa" de um consagrado mote neoliberal: ${ }^{27}$ "não há alternativas", ou pior, "não há o que discutir" (Paoli, 1999, p. 10). No detalhe: trata-se de uma postura ambivalente, dado que, por um lado, devido a seu caráter etnográfico e experimental, ela ganha ao desmistificar rótulos tais como "os excluídos" ou "a pobreza", distribuídos e consagrados pelo senso comum acadêmico, e que têm pouco a dizer a respeito das atuais realidades urbanas. Por outro, no entanto, tal postura opera a partir de uma dupla recusa, utópica e sociológica, esta como que justificando metodologicamente aquela e autorizando a desutopização da perspectiva, que, como vimos, só pode apontar para o inapelável. Ora, se a demissão de uma perspectiva normativamente orientada tem sua justificação teórico-metodológica, isso não significa que essa dupla

\footnotetext{
${ }^{27}$ Novamente, me aproprio da elaboração de Paoli, que diz: "[O] mote liberal é, exatamente, a insistência na frase "não há alternativas"” (1999, p. 15).
} 
recusa esteja desprovida de seu próprio enraizamento - ela fala a partir de algum lugar. Esse lugar nós procuraremos na dissecação da concepção negativa de política hoje corrente no Cenedic e, por fim, na forma atualizada e assumida pelo debate herdado dos anos 1980, a partir de quando aquela aposta foi gestada, parida e, mais recentemente, morta.

Três epitáfios para um obituário: "A pobreza e a sua superação eram a nossa chance histórica!”, exclama Schwarz (2003, p. 19 - grifos no original).

"Faltou vontade para aproveitar a 'riqueza da iniquidade' de ser periferia, em benefício de um projeto de nação"; e prossegue Laymert Garcia dos Santos, "[o] ornitorrinco que é o Brasil apresenta-se, portanto, como uma evolução sem saída" (Santos, 2007, pp. 301-302).

E, por fim, no luto da utopia,

"[o debate dos anos 1980] mobilizava a imaginação crítica na aposta de que seria possível superar as mazelas da sociedade e trazer as maiorias [...] ao universo da cidadania ampliada [...]. Pois bem, essa aposta foi perdida. Ao menos, foram desestabilizados os termos em que foi formulada" (Telles, 2006a, p. 41).

Bastante ligada ao diagnóstico de Schwarz, Telles se questiona se a década de 1980 teria visto o último capítulo de um debate que girava em torno de noções como "superação" e "aspirações à modernidade". Tal como Laymert dos Santos, essa autora se utiliza da imagem d'O Ornitorrinco de Chico de Oliveira para

"descrever o país: um monstrengo feito de pedaços desconjuntados, diferenças, defasagens, descompassos, desigualdades, que, não sendo mais atravessados por uma 
virtualidade de futuro, não mais articulados por uma 'dialética dos contrários', ficam onde estão, um neoatraso, [...], fatos irrevogáveis de nossa realidade, sem solução e sem superação possível no cenário do capitalismo globalizado [...]" (Telles, 2006a, pp. 41-42).

Nesse cenário "sem saída" e "sem solução" não é de espantar que uma noção como a de cidadania, cujo potencial teórico-político segundo os teóricos do Cenedic teria morrido em algum momento da década de 1990, tenha assumido a função pretérita de falar do passado e daquilo que ele não foi. Por outro lado, entretanto, espanta a concepção de política que, especialmente após a publicação d'O Ornitorrinco, passou a ser a base mesma da crítica "perplexa". As categorias em torno das quais se estruturam a versão desencantada de política são várias: "trabalho sem formas", "Estado ad hoc", "exceção permanente", "destruição da política", "neoatraso", "anulação do dissenso", "ação anticomunicativa", "antipolítica" - a lista é longa. Obviamente, já não se trata mais daquela noção conflituosa e dissensual, historicamente possível de política. Na direção precisamente oposta, a crítica desses autores aponta para a própria impossibilidade de sua prática, aponta para a "não política". Impossível que é, ela opera só e soberana pela sua negatividade: no contexto pós-1990, "o terreno do conflito foi modificado e, por isso, não há 'política', [há] apenas 'polícia' representada nos programas dos partidos” (Oliveira, 2003a, p. 212).${ }^{28}$ Desempenhando a um só tempo função normativa e de pressuposto argumentativo, essa concepção negativa de política atravessa e alinha todas as reflexões cristalizadas em "A era da indeterminação”. Os exemplos empíricos variam, a constatação permanece: em face da administração e da despolitização

\footnotetext{
${ }^{28}$ Este trecho leva tom ainda mais desencantado em versão posterior: "não pode haver política, nem polícia: há apenas administração" (Oliveira, 2006, p. 276 - grifos no original).
} 
vencedoras, não há resistência, ambiguidade e tampouco contradição - no limite, tudo se passa como se não houvesse mais história. O que o modelo neoliberal de natureza totalitária produziu foi um sistema-monstro: "é uma dominação que se faz pelo terror, diretamente, sem mediações. É uma dominação sem política" (Oliveira, 2006, p. 287). O que a crítica perplexa quer fazer ver é a morte da política, sua substituição pela administração e pelas técnicas de gestão.

Recorrendo a Laymert Garcia dos Santos, um dos mais presentes interlocutores do Cenedic, poderíamos dizer que, mesmo nesse cenário domesticado, administrado e desmanchado, há um espaço mínimo para a política, diz ele:

"[o] texto que anuncia a era da indeterminação não a considera a era do fim do conflito. Na intransparência, na opacidade, há luta" (Santos, 2007, p. 296).

O próprio subtítulo do texto de Francisco de Oliveira assim indica - "opacidade e reencantamento":

"A indeterminação, não significa o estancamento das experimentações inventivas; quer dizer apenas que elas ainda não cristalizaram o campo de conflitos dentro do qual os atores devem se movimentar doravante" (Oliveira, 2007, p.43).

Em uma intrincada dialética, o reencanto da crítica desencantada se escora em "fatos" ou "raros momentos" fundamentalmente mediados por um "não mais e não ainda", ${ }^{29}$ por um "talvez":

"Mas talvez, na singularidade conflituosa deste país, certos fatos apontem para algumas brechas significativas em relação à aceitação deste mundo gerido e incerto, e que aparecem

${ }^{29}$ Veja Paoli (2006). 
em todos os casos citados neste texto. Os trabalhadores domesticados pela inédita racionalidade prática fabril fizeram greve que, no momento, ressuscitaram a crítica. [...] Um jovem entrevistado, preso entre a carência e a polícia, encontrou nas letras do hip hop uma identidade crítica, narrando sua história nesse mesmo ritmo. [...] Talvez se possa pensar, para esses sinais contingentes de busca de sentido, $[\ldots]$ o pequeno espaço intemporal no próprio âmago do tempo, em que o pensamento, a recordação e a antecipação salvam da ruína do tempo e constituem os raros momentos abertos para a possibilidade da política" (Paoli, 2007, p. 256).

Ainda que esses raros reencantamentos sejam passíveis de reconhecimento, o quadro teórico-normativo que dá inteligibilidade a eles é, relativamente ao estatuto da política, basicamente negativo: o chamado "desmanche" é antes de tudo o desmanche da política, e suas extrapolação e indeterminação são econômicas.

"Não há volta. A economia domina inteiramente a política - e essa parece ser a contra-revolução do nosso tempo" (Santos, 2007, p. 311).

"Na base da tecnocratização do governo, há o fato de a política ter sido engolida pela economia" (Paoli, 2007, p. 246).

Indireta e consequentemente,

"[a] possibilidade mesma de constituição de sujeitos políticos foi erodida em suas bases" (Telles, 2006b, p. 186).

É fundamental não se enganar quanto ao ponto aqui em questão: a complexidade da crítica dos sociólogos do Cenedic prescinde de qualquer determinismo, seja ele infraestrutural ou tecnológico. Levar a discussão a termos de um deba- 
te caro a diferentes tradições marxistas, não apenas geraria uma estéril batalha teórica, como também faria perder de vista a maior contribuição deste grupo de teóricos para o debate político brasileiro: agrupados ao redor das reflexões de Chico de Oliveira, a crítica perplexa nos mostra as formas insidiosas através das quais a privatização e o confinamento do público e, sobretudo, do conflito político-público, tanto se travestem sob o rótulo de "racionais", "do Mercado" ou "do Terceiro Setor", quanto forjam um mundo pretensamente harmônico e reificado, cheio de "parcerias" e de "empreendedores", repleto de "vencedores”, cuja força ideológica se traduz na adesão via senso comum aceito, incorporado e reproduzido. Essa naturalização insidiosa se dá no bojo de uma normalização democrática transcorrida junto da transformação da morfologia internacional do capital e na concorrência com a internalização dos interesses e "ajustes" neoliberais. Bem entendida, essa crítica não se confunde com

290 o clichê reinante e equívoco segundo o qual "o-econômicodetermina-o-político"; ao contrário, ela aponta para o fato de que, em tempos neoliberais, as relações e regulamentações políticas perdem força civilizatória e de decisão no enquadramento de um processo econômico que se pretende autônomo em relação àquelas formas de regulação, que se pretende Mercado tout court. Para entender os sentidos da democracia brasileira, essa crítica e a perversão que ela explicita não são desimportantes e tampouco podem ser desconsideradas.

A questão é antes os limites impostos pelo enquadramento no interior do qual essa crítica se desenrola. Esse enquadramento está como que contornado por duas ideiaslimite: desmanche e exceção. No intervalo entre essas duas noções, giram outras categorias que, em negativo, tentam dar conta da "virada dos tempos".

“[As] conexões que articulavam o 'Estado e o urbano', por exemplo, foram cortadas ou viradas pelo avesso sob a 
lógica de um duplo desmanche, por cima e por baixo [...] O que antes era percebido como exceção [...] transforma-se em regra - as desigualdades abissais, a pobreza urbana, o 'trabalho sem forma' [...], bem, tudo isso está aí para ficar" (Telles, 2006a, p. 42).

Essa passagem sintetiza o tom hipercrítico de abordagem hoje corrente no Cenedic e, de quebra, traz algumas das categorias e inspirações teóricas que acabam por absolutizar tendências contemporaneamente dominantes e, indiretamente, por fixá-las em algo como um fim - como se isso fosse possível. Note: à crítica do neoliberalismo perverso sustentada por esses teóricos corresponde uma reconstrução igualmente crítica: a reconstrução da experiência vivida pelos sujeitos na era do desmanche. Exemplo brilhante dessa dupla tarefa está, a meu ver, na análise feita por Chico de Oliveira, em "Os sentidos da democracia”, a respeito das novas formas de subjetivação de dominantes e de dominados relativamente à aparente, falsa e desmoralizante desnecessidade do público, levadas a cabo nos 1990. No entanto, a despeito da força de tal reconstrução, resta ainda algo. Se permanece satisfeita com isso, a crítica fica, por assim dizer, capenga, ela não chega a se completar. Isso porque no recalque do componente utópico se dá o encapsulamento da crítica, que, embora seja capaz de lançar luz sobre as tendências e leis essenciais de nossa sociedade, não é capaz de ver que aí

“também se encerram a possibilidade ou o potencial para que a sociedade cesse de ser a associação coercitiva em que nos encontramos e possa ser diferente" (Adorno, 2008, p. 87).

Ou seja, após ter descortinado a perversão neoliberal e o ego desfigurado por ela exigido e produzido, a postura 
perplexa fica sem horizontes e, porquanto limitada a negatividades categoriais múltiplas, cujas raízes vão de Benjamin a Zizek a Agambem, pode até "mobilizar nos fenômenos o que fez que estes se tornaram aquilo em que se converteram", mas não chega a "apreender [nesses fenômenos] uma outra possibilidade de vir-a-ser e converter-se em algo outro" (Adorno, 2008, pp. 336-337). Laymert dos Santos (2006) sintetiza: "o presente é duplamente excepcional”, nele se desenha um "horizonte puramente negativo", precisamente quando o "povo queria ver o raiar de um novo dia".

Se, nesses termos, o "novo" é nada menos que uma impossibilidade, poderíamos recorrer àquela passagem marcada por um pontencial "talvez" e procurar alguma forma de luta ou raros reencantamentos. Isso, no entanto, não ajudaria muito, pois, ainda que seja possível ver nas letras do hip hop uma forma de resistência, o tom geral da orques-

292 tra cognitiva está mais próximo de um réquiem, que toca mais ao fundo, muito parecido com funk do tipo “...tá tudo dominado!". Dados e fatos da concretude vivida não cansam de provar: tânatos, o que há hoje é violência e administração da pobreza, anomia durkheimiana em estado puro. Em tempo de exceção e de pobreza funcional e funcionalizada, o Estado é dominado por uma classe ornitorrínquica e, no mundo vida, para os sobreviventes movimentos sociais e ONGs, fica o papel de "parceiros", coadjuvantes da privatização do público e da anulação do dissenso. Resta pouco e o pouco que resta, a começar pela própria metáfora do ornitorrinco, "um bicho que não é isso nem aquilo", "este não-ser” (Schwarz, 2003, pp. 12 e 15), só pode ser explicado em negativo. É neste ritmo que rege o crítico:

"é vertiginoso e inusitado o andamento das categorias: estão em formação, já perderam a atualidade, não vieram a ser, trocam de sentido, são alheias etc." (Schwarz, 2003, p. 16). 
Essa vontade de explicar o "Brasil" ou a realidade brasileira pelas suas ausências, pelas suas privações, por aquilo que não conseguimos ser, que já não somos e não seremos, como notou Chauí, vem de longa data na história das interpretações de nossas indeterminações. Em nossa era, mais uma indeterminação: "do lado de cima, o vazio, e do lado de baixo, o desvio" (Chauí, 1978, p. 21 - grifos no original); e no meio (ou seja, nas arenas nas quais debatem e se debatem atores civis e estatais), nada ou, ao menos, nada que encerre virtualidades, contradições e potencialidades. Não se trata de negatividade determinada, cujo corolário é uma produtividade contraditória, se trata de uma negativa pura. ${ }^{30}$ Entre a exceção e o desmanche, e ao redor da política agora sepultada, circulam várias quasi categorias que podem entrar para um consagrado rol de ideias "como atraso, tardio, vazio, despreparo, imaturidade, importação de ideias, etc." (Chauí, 1978, p. 25).

Como compreender a perplexidade dessa versão negativa e impossível de política? Responder tal questão torna-se ainda mais complexo uma vez considerado o tom predominante pouco tempo antes nessa mesma posição de crítica. Como entender uma postura que ora enfatiza a construção pública e conflituosa do consenso, ora enfatiza uma "hegemonia às avessas"? ${ }^{31}$ Como dialogam a ideia de que atualmente transcorre a "funcionalização da pobreza" e a

\footnotetext{
${ }^{30}$ Mesmo se lembrarmos que em Adorno, do ponto de vista da análise, a negação é a única postura digna do adjetivo "crítico", nada permite que a análise seja absolutizada pelas tendências dominantes, falsas e falsificantes, do mundo administrado. Dito de outra forma, a reificação do mundo não implica necessariamente a demissão da crítica, que pode explorar dialeticamente o par ilusão/potência. "Os sujeitos", diz Adorno, "são hoje como se fossem momentos negativos [...]. Poderíamos afirmar que, em sua conformação vigente, o sujeito é ambas as coisas: de um lado, ideologia, justamente porque ele não é decisivo e simplesmente porque sentir-se como sujeito nessa sociedade já é algo ilusório; de outro, contudo, ele é potencial, o único potencial por meio do qual essa sociedade pode se transformar, em que se acumula não só toda a negatividade do sistema, como também tudo o que aponta para além deste em sua forma vigente" (2008, pp. 341-342).

${ }^{31}$ Veja Oliveira (2007b).
} 
perspectiva anterior de que mesmo garantias formais são fundamentais? ${ }^{32}$

A resposta oferecida para a compreensão do desencanto é inequívoca: "Desconhecer a tendência nova", afirma Roberto Schwarz, "ou [desconhecer] a data vencida de convicções que estão na praça seria uma ignorância”. Daí decorre em registro materialista que

"[o] atualismo sem otimismo ou ilusões é uma posição complexa, profundamente real, base de uma consciência que não se mutila, ao mesmo tempo que é rigorosa" (Schwarz, 2003. pp. 16-17).

O conjunto de reflexões de "A era da indeterminação" endossa a posição do crítico: a "virada dos tempos" ou o "trabalho de desmanche" desencantou a aposta dos e nos 1990.

Essa, contudo, é apenas uma meia resposta. Reconhecer a orientação de fato perversa assumida pela "tendência nova”, isto é, pela democracia brasileira no contexto do capitalismo globalizado e da implementação do modelo neoliberal e, por essa via, indicá-la como única ou principal variável na produção do desencanto teórico-político, não responde inteiramente àquelas questões. Seguramente, não se trata de "desconhecer a data vencida das convicções", trata-se, antes, de historicizar as próprias convicções e, nelas, o seu prazo de validade. Do contrário, bastaria dizer que as posturas dos anos 1990 seriam ou menos "profundamente reais” ou apenas ideologizadas e ilusórias. Ora, desde sua síntese paradigmática no fim dos 1980, na reflexão empre-

\footnotetext{
32 "Não fiquemos de novo com a velha história que dizia, durante a minha formação de esquerda, que as garantias eram burguesas e, portanto, nada tinham a ver com os ideais de esquerda. As garantias são fundamentais. (Quem passou pelas prisões do Estado sabe a diferença entre garantias formais e não garantias formais.) Isso faz uma diferença enorme" (Oliveira, 1994b, p. 15).
} 
endida por Sader, a aposta dos intelectuais de esquerda democrática já continha sua autocrítica naquilo que ela poderia ser ou mesmo queria ser iludida: refiro-me menos à hoje célebre afirmação de Francisco Weffort sobre a necessidade de se inventar uma sociedade civil, e mais à capacidade reflexiva de Sader de lidar com os ataques dirigidos contra a promessa encerrada naqueles "novos personagens" e contra a aposta nesses mesmos atores.

“[O] projeto político implícito nos movimentos sociais do fim da década de 1970 sofreu uma derrota. Eé por isso mesmo que hoje suas promessas são vistas frequentemente como ilusões, mistificações, erros de avaliação. Mas a verdade é que toda representação passada contém 'ilusões', [...] [e ainda] que não tenhamos mais as 'ilusões' que tínhamos há 8 anos, não podemos cancelar o fato de que efetivamente aqueles movimentos eram portadores daquelas promessas e tiveram aqueles significados enquanto possibilidades postas numa situação aberta.” (Sader, 1988, pp. 314-315 grifos meus).

O diagnóstico da potencialidade encerrada naqueles "portadores" jamais se configurou como uma confusão impensada, quer dizer, em nenhum momento, diferentemente do que afirmou F. Cardoso (1993), a assim rotulada postura "basista" foi "cega". Bem entendida, a aposta de construção político-hegemônica não foi mera "ilusão" ou meramente "ideológica”. Essa passagem de Sader dá uma incômoda, e atualmente bastante necessária, sensação de déjà vu: ontem, da mesmíssima forma que hoje, o projeto dos movimentos sociais sofreu uma derrota, mais uma - e dizer isso, de fato, se tornou lugar comum. ${ }^{33}$ Como postura

\footnotetext{
${ }^{33} \mathrm{O}$ mais recente obituário dos movimentos sociais - porque supostamente e totalmente cooptados, é claro - pode ser visto na Folha de S.Paulo de 20 de outubro de 2009.
} 
teórico-política, a aposta daqueles intelectuais de esquerda democrática era uma postura consciente alicerçada em uma utopia cujo ponto de partida não pretendia de antemão negar as "promessas", as possibilidades encerradas naquelas novas personagens e nas mudanças assinaladas por sua entrada no mundo público. Ter essa "ilusão" própria, tê-la de forma provisória e autocriticada, ou seja, apegar-se à "ideologia dos movimentos sociais" sem qualificá-la sob rótulos absolutizantes, sejam eles positivos ou negativos, é condição de possibilidade intelectual para criticamente ver aí mesmo suas contradições e ambiguidades, sejam elas potenciais ou reais. A afirmação positiva e positivada daqueles "portadores de promessas” foi uma posição político-intelectual defendida, na esteira de autores como Chauí, Sader e Paoli, pelo conjunto dos intelectuais hoje agrupados no Cenedic. Tais positividade e potencialidade podem ser entendidas na relação de oposição aos ataques contra sua postura inter-

296 pretativa e contra as dúvidas colocadas quanto à "política dos outros" (na sintomática alcunha de Teresa Caldeira) que deram o tom daquela pugna intelectual, gestada nos 1980 e fortemente atualizada na década seguinte.

De um lado estavam as perspectivas que, bastante afins à cautela metodológica de Ruth Cardoso, afirmavam que adjetivar de "político" os movimentos sociais - como vimos, "decretar o nascimento de novos atores políticos" (Cardoso, 1983, p. 219) - e imputar-lhes qualquer "força transformadora" era no mínimo "incompleto", ainda que eventualmente eles pudessem vir a ser uma "nova peça no jogo político" já dado. Nesta mesma toada, Renato Boschi, por exemplo, sustentava que,

"embora o conjunto de trabalhos tenha o mérito de registrar diversos casos e experiências, a avaliação do impacto político dos movimentos sociais é geralmente inadequada" (Boschi, 1987, p. 43). 
Segundo ele, tal "inadequação" se deve aos "pressupostos ideológicos" das análises, à valorização da "participação em detrimento da representação", bem como ao "exagero sobre a real extensão dos movimentos"; contra tais equívocos, o autor exige e parte de uma "teoria dos efeitos político-institucionais da ação coletiva” (Boschi, pp. 43-44), de forma a reduzir mais uma vez a política ao seu âmbito institucional. Ora, como vimos, a afirmação do caráter político das relações então instauradas pela performance dos movimentos sociais dependia da capacidade e da vontade intelectuais de vê-los e situá-los dentro de uma conflituosa e pública arena de relações. É, portanto, a partir dessa posição no outro lado da pugna em torno da "real extensão dos movimentos" que deriva a adequada adjudicação do seu caráter político. A visada dos intelectuais posteriormente agrupados no Cenedic era, pois, ousada a ponto de "pensar a política como algo que não se reduz a um único espaço, prefixado e determinado ao Estado e das relações institucionalizadas de poder" (Telles, 1988, p. 281).

É na relação de oposição àquele tipo de postura, que cínica ou iludidamente desideologizada se voltava para os limites e velhos clientelismos e conservadorismos atualizados pelos "novos" movimentos, ${ }^{34}$ que a aposta nos 1990 tem uma de suas raízes. Neste sentido, evidência do peso do debate sobre a orientação político-normativa das respectivas interpretações pode ser encontrada no diálogo travado por Chico de Oliveira com uma organização civil:

"Uma certa Sociologia [...] e uma Ciência Política bastante formalizada não conseguia[m] captar [o processo de democratização], [...], ambas olhavam com desprezo os movimentos sociais e viam neles o basismo. O melhor título para essa arrogância intelectual talvez seja o de um velho

\footnotetext{
${ }^{34}$ Veja Perruso (2009, cap. 4, em especial).
} 
filme do neorrealismo italiano: 'Feios, Sujos e Malvados'. A Sociologia e a Ciência Política olhavam para os movimentos sociais como uma coisa persistente, chata, exigente de transparência e que foi denunciada muitas vezes como um movimento da antipolítica" (Oliveira, 1994b, p. 11).

De outro lado, estão as críticas que, na esteira de Oliveira, se dirigem à "arrogância intelectual" daqueles que viam a performance dos movimentos sociais como "antipolítica" e cuja interpretação enfatizava o "basismo" - definido por R. Cardoso como a "ideologia da valorização das bases" (1983, p. 287); dirigem-se à indicação sub-reptícia de que, a despeito da luta antiautoritarismo ser "comum a todos", o espaço da política seria teoricamente adequado se reservado a atores supostamente mais competentes que as bases. Da mesma forma que em sua "Carta aberta" dirigida ao então Ministro-sociólogo, a crítica de Chico de Oliveira, na passagem acima, se volta con298 tra o ranço elitista, decisionista e "autoritário" de tais tipos de interpretação e de ação políticas, justamente porquanto tal ranço oblitera, de saída, a compreensão do sentido (na dupla acepção do termo) da disputa pelos significados e pelos limites da política. Quase uma década depois, Ruth Cardoso se perguntou se aquilo que via nas reivindicações dos movimentos sociais de frente para o Estado era política, mas, àquela altura, ela já estava disposta a presentear esses "outros" com uma resposta positiva.

Essas passagens bastam para ilustrar como, apesar de ampla produção ter atravessado e adensado quase uma década de debate, a dinâmica de oposição e de não complementaridade entre as partes deu o tom das respectivas posições. É em relação a essa dinâmica específica, ou seja, é em relação ao caráter antitético assumido pela disputa teórica, sintetizado de forma exemplar na adjudicação daquilo que merecia ou não o adjetivo "político", que se pode compreender o otimismo veiculado pela produção de parte central 
do grupo de autores que, posteriormente, se agrupou em torno do Cenedic. Quer dizer, o conjunto de índices normativos e de dispositivos analíticos por eles acionado para dar inteligibilidade aos rumos da democracia deita suas raízes na antítese constitutiva das trocas, até então, em debate. Certamente, para além do mundo acadêmico, as subjetividades investidas e envolvidas na disputa do que é ou não é político se implicaram em vários outros campos de força, seja na sociedade civil seja no universo político-partidário. As experiências por eles vividas e analisadas durante os anos 1990 levavam à constatação do potencial democratizante e civilizatório dessa década. No entanto, no meio do caminho, a forma perversa do neoliberalismo à brasileira deixou tal crítica em estado perplexo. E aqui voltamos àquela antítese: o desencanto teórico-político, a desutopização da perspectiva e a concepção negativa de política não são apenas, e tampouco, sobretudo, resultado do desmanche neoliberal. Imputar à "virada dos tempos" ou ao "movimento do real" a mudança ocorrida na própria postura interpretativa é seguir negando a autoanálise, é evitar a análise da teia de relações nas quais aquela aposta foi feita. Nesse mesmo sentido, dizer dela ideológica ou ilusória opera apenas como mecanismo de defesa intelectual, na medida em que sua desqualificação corresponde a uma forma de denegação e, por essa via, autoriza o uso irrefletido da concepção negativa de política. Ambas, aposta e perplexidade, são as duas faces da mesma moeda, de uma só subjetividade. Dando outro rumo a uma pista dada por Telles, diria que a questão não é tanto refletir sobre "dois registros", sobre um Lefort lá e outro Agambem cá, mas tomá-los como um único e mesmo registro, pois a perplexidade é em grande medida produto da atualização do debate dos anos 1980 e uma "inversão dos sinais" 35 daquele debate - dado que hoje, infelizmente,

${ }^{35}$ Veja Dagnino (2004, pp. 139-140). 
cabe à crítica perplexa a liderança na disputa pela posição de algoz da política.

Quem disse "não há alternativas”? À postura crítica resta, mais uma vez, contestar essa negativa.

\section{José Szwako}

é doutorando em Ciências Sociais - Unicamp

\section{Referências bibliográficas}

ADORNO, T. 2008. Introdução à sociologia. Trad. Wolfgang Leo Maar. São Paulo: Ed. Unesp.

ALEXANDER, J. 1987. "O novo movimento teórico". Revista Brasileira de Ciências Sociais, vol. 2, nº 4, pp. 5-28.

BASUALDO, E.; ARCEO, E. (orgs.). 2006. Neoliberalismo e sectores dominantes. Tendencias globales y experiencias locales. Buenos Aires: Clacso.

BOSCHI, R. R. 1987. A arte da associação: política de base e democracia no Brasil. São Paulo: Vértice.

CARDOSO, F. H. 1993. "Regime político e mudança social: a transição para a democracia”. A construção da democracia: estudos sobre política. São Paulo: Siciliano.

CARDOSO, R. L. 1983. "Movimentos sociais urbanos: balanço crítico". In: SORJ, B.; TAVARES, M. H. Sociedade e política no Brasil pós-64. São Paulo: Brasiliense.

(org.). 1986. A aventura antropológica: teoria e pesquisa. Rio de Janeiro: Paz e Terra.

. 1988. "Isso é política? Dilemas da participação entre o moderno e o pós-moderno”. Novos Estudos Cebrap, 20, pp. 74-80.

. 1994. "A trajetória dos movimentos sociais". In: DAGNINO, E. (org.). Os anos 90: politica e sociedade no Brasil. São Paulo: Brasiliense.

CHAUÍ, M. 1978. Ideologia e mobilização popular. Rio: Paz e Terra/Cedec. . et al. 1980. “A Democracia é Possível?”. In: Lua Nova, nº 2.

DAGNINO, E. 2002. "Sociedade civil, espaços públicos e a construção democrática no Brasil: limites e possibilidades". In: Sociedade Civil e Espaços Públicos no Brasil. São Paulo: Paz e Terra.

. 2004. "Construção democrática, neoliberalismo e participação: os dilemas da confluência perversa”. Política $\mathcal{E} \mathcal{O}$ Sociedade, $\mathrm{n}^{\circ} 5$, Florianópolis: Editora:. Cidade Futura/UFSC, outubro, pp. 137-161.

.; TATAGIBA, L. (orgs.). 2007. Democracia, sociedade civil e participação. Chapeco: Argos. 
OLIVEIRA, F. 1993a. "Carta aberta ao ministro Fernando Henrique Cardoso". Folha de S.Paulo, 6/6/1993. . et al. 1993b. "Quanto melhor, melhor: o acordo das montadoras", Novos Estudos Cebrap 36. São Paulo, pp. 3-7, julho.

. 1994a. "A prova dos nove: conflito de classes, publicização e nova contratualidade". O Brasil no rastro da crise. São Paulo: Hucitec/Anpocs. . 1994b. "Estado, sociedade, movimentos sociais e políticas públicas no limiar do século XXI”. Rio de Janeiro, RJ. FASE - Programa de investigação e comunicação. Federação de Órgãos para Assistência Social e Educacional.

. 1999. "Privatização do público, destituição da fala e anulação da política: o totalitarismo neoliberal”. Os Sentidos da democracia. Petrópolis, RJ: Vozes.

. 2000. Dossiê Projeto Brasil: alternativas para o século XXI. Revista USP. São Paulo, nº 47, pp. 6-28, setembro/dezembro.

. 2003a. Política numa era de indeterminação: opacidade e reencantamento. In: SILVA, F. et al. Republicanismo, Liberalismo e Cidadania. Piracicaba, SP: Ed. Unimep.

. 2003b. Crítica à razão dualista/O Ornitorrinco. São Paulo: Boitempo Editorial.

. 2006. "A dominação globalizada: estrutura e dinâmica da dominação burguesa no Brasil”. In: BASUALDO, E.; ARCEO, E. (orgs.). Neoliberalismo e sectores dominantes. Tendencias globales y experiencias locales. Buenos Aires, Clacso.

. 2007a. Política numa era de indeterminação: opacidade e reencantamento. In: A era da indeterminação. São Paulo: Boitempo, Coleção Estado de Sítio.

. 2007b. "Hegemonia às avessas". Revista Piauí, 4. Rio-São Paulo: Ed. Alvinegra, jan 2007.

.; PAOLI, M. C. (orgs.) 1999. Os sentidos da democracia. Petrópolis, RJ: Vozes.

; RIZEK, C. (orgs.). 2007. A era da indeterminação. São Paulo: Boitempo.

PAOLI, M. C. 1989. “Trabalhadores e cidadania. Experiência no mundo público da história do Brasil moderno”. Estudos Avançados. São Paulo: Ed. USP.

. 1992. "Memória, história e cidadania: O direito ao passado". In: O direito à memória: patrimônio histórico e cidadania. São Paulo: DPH. . 1995a. "Movimentos sociais no Brasil: em busca de um estatuto político”. In: Movimentos sociais e democracia no Brasil. São Paulo: Marco Zero. 
1999. Apresentação e introdução. In: OLIVEIRA, F.; PAOLI, M.

C. Os sentidos da democracia. Petrópolis, RJ: Vozes.

. 2002. "Empresas e responsabilidade social: os enredamentos da

cidadania no Brasil". In: Democratizar a democracia: os caminhos da democracia participativa. Rio de Janeiro: Civilização Brasileira.

. 2006. "Não mais e não ainda: invenção e emergência em Chico de Oliveira”. In: RIZEK, C.; ROMAO, W. (orgs.). Francisco de Oliveira: a tarefa da crítica. Belo Horizonte: Ed. UFMG.

. 2007. "O mundo do indistinto: sobre gestão, violência e política”. In: A era da indeterminação. São Paulo: Boitempo. Coleção Estado de Sítio.

PERRUSO, M. 2009. Em busca do “novo": intelectuais brasileiros e movimentos populares nos anos 1970/80. São Paulo: Annablume.

RIZEK, C.; ROMAO, W. (orgs.). 2006. Francisco de Oliveira: a tarefa da crítica. Belo Horizonte: Ed. UFMG.

SADER, E. 1988. Quando novos personagens entram em cena: experiências, falas e lutas dos trabalhadores da Grande São Paulo: 1970-80. Rio de Janeiro: Paz e Terra.

; PAOLI, M. C. 1986. "Sobre 'classes populares' no pensamento sociológico brasileiro Notas de leitura sobre acontecimentos recentes”. In: CARDOSO, R. (org.). A aventura antropológica: teoria e pesquisa. Rio de Janeiro: Paz e Terra.

SANTOS, L. G. 2006. "Instituição e destituição do mundo público: invenção e anulação”. In: Francisco de Oliveira: a tarefa da crítica. Belo Horizonte: Ed. UFMG.

. 2007. "Brasil contemporâneo: estado de exceção?". A era da indeterminação. São Paulo: Boitempo. Coleção Estado de Sítio.

SANTOS, W. G. 1993. Razões da desordem. Rio de Janeiro: Rocco.

SCHWARZ, R. 2003. Prefácio com perguntas. In: Crítica à razão dualista/O Ornitorrinco. São Paulo: Boitempo Editorial.

SILVA, F. et al. 2003. Republicanismo, liberalismo e cidadania. Piracicaba, SP: Ed. Unimep.

SORJ, B.; TAVARES, M. H. 1983. Sociedade e política no Brasil pós-64. São Paulo: Brasiliense.

TELLES, V. S. 1988. “Anos 70: experiências, práticas e espaços políticos”. In: As lutas sociais e a cidade. Rio: Paz e Terra.

- 1994. "Pobreza, movimentos sociais e cultura política: Notas sobre as difíceis. relações entre pobreza, direitos e democracia”. In: $O$ Brasil no rastro da crise. São Paulo: Hucitec/Anpocs.

Paulo.

1998. "Direitos sociais: afinal do que se trata?". Revista USP, São 
2001. "A cidade e o trabalho": In: Cadernos Le Monde Diplomatique, São Paulo, janeiro.

. 2006a. "Debates: a cidade como questão". In: TELLES, V.; CABA-

NES, R. (orgs.). Nas tramas da cidade. Trajetórias urbanas e seus territórios.

São Paulo: Associação Editorial Humanitas,. 2006b. "Trabalho, cidade e os elos perdidos da política". In: RIZEK, C.; ROMAO, W. (org.). Francisco de Oliveira: a tarefa da crítica. Belo Horizonte: Ed. UFMG.

. 2007a. "Transitando na linha de sombra, tecendo as tramas da cidade”. In: OLIVEIRA, F.; RIZEK, C. (orgs.). A era da indeterminação. São Paulo: Boitempo.

. 2007b. "Trajetórias urbanas: fios de uma descrição da cidade".

In: DAGNINO, E.; TATAGIBA, L. (orgs.). Democracia, sociedade civil e participação. Chapeco: Argos.

.; CABANES, R. (org.). 2006. Nas tramas da cidade. Trajetórias urbanas e seus territórios. São Paulo: Associação Editorial Humanitas.

.; CABANES, R. 2006. Introdução. In: TELLES, V.; CABANES, R. (org.). Nas tramas da cidade. Trajetórias urbanas e seus territórios. São Paulo: Associação Editorial Humanitas.

.; HIRATA, D. V. 2007. "Cidade e práticas urbanas: nas fronteiras incertas entre o ilegal, o informal e o ilícito". Revista Estudos Avançados, vol. $21, \mathrm{n}^{\circ} 61$, pp. 173-191. 


\section{OS SENTIDOS DA DEMOCRACIA: CRÍTICA, APOSTA E PERPLEXIDADE NA PRODUÇÃO DO CENEDIC}

JOSÉ SZWAKO

O texto acompanha a trajetória das noções de "política" e "cidadania” na reflexão de Maria Célia Paoli, Vera da Silva Telles e Francisco de Oliveira, do começo dos anos 1990 até a publicação de $A$ era da indeterminação, de 2007. Ao início desse percurso, a série de afinidades e aproximações entre estes sociólogos permite observar o tipo de aposta por eles feita no potencial democratizante encerrado nos movimentos sociais e, mais amplamente, na construção político-hegemônica que então se desenhava. Após ter acompanhado tanto o desencanto com as promessas daquela década quanto a principal inflexão normativa ocorrida na produção destes intelectuais, hoje reunidos no Cenedic, o argumento final se volta para a concepção negativa de política corrente em suas análises e a situa no espaço dos embates, oposições e "ilusões" que, desde os anos 1980, marcaram as interpretações sobre os sentidos da democracia brasileira.

Palavras-chave: Crítica; Democracia brasileira; Utopia. 